\title{
Criminal Action of Cosmetics Without License in Conception of Legal Expression
}

\author{
Lutfi Anindita*) and Bambang Tri Bawono**) \\ *) Master of Law, Faculty of Law, Universitas Islam Sultan Agung Semarang, E-mail: \\ lutfianindita25@yahoo.co.id \\ **) Faculty of Law, Universitas Islam Sultan Agung Semarang
}

\begin{abstract}
.
The purpose of this study is to determine and analyze the investigator's authority to handle the distribution of cosmetics without a permit in the construction of the legal system. To find out and analyze the implementation of Article 197 in conjunction with Article 106 paragraph (1) subside Article 196 in conjunction with Article 98 paragraph (2) and paragraph (3) of Act No. 36 of 2009 concerning Health in the conception of legal certainty. The approach method used in the preparation of this legal writing is to use a sociological juridical approach, namely seeing the law as human behavior in society.The specification of this research is descriptive analytical. Based on the results of that research The authorities of investigators to handle the unauthorized distribution of cosmetics in the construction of the legal system include: to receive reports or complaints from someone about the existence of a criminal act; take the first action at the scene; order a suspect to stop and check the suspect's identification; carry out an arrest, detention, search and confiscation; carry out inspection and confiscation of letters; take fingerprints and take a picture of a person; summon people to be heard and examined as suspects or witnesses; bring in the necessary experts in connection with the case examination; to terminate the investigation; take other action according tolaw responsible. Implementation of Article 197 in conjunction with Article 106 paragraph (1) subsidiary to Article 196 in conjunction with Article 98 paragraph (2) and paragraph (3) of Act No. 36 of 2009 concerning Health in the conception of legal certainty it is very appropriate to receive appropriate punishment because actions are very detrimental to the wider community both from an economic, social, and cultural perspective.
\end{abstract}

Keywords: Crime; Cosmetics; Legal Certainty.

\section{Introduction}

As stated in Article 1 paragraph (3) of the 1945 Law of the Republic of Indonesia which states that "the State of Indonesia is a State of Law" where the provisions of the Article constitute the constitutional basis that Indonesia is a country based on law. In this case, law is positioned as the only reference in the life of society, nation and state. The rule of law requires that the law must always be enforced, respected and obeyed by anyone without any exceptions. This aims to create security, order, welfare in society and the state.

To achieve this national goal, a sustainable development effort is carried out which is a series of comprehensive and integrated development, including development in the health sector. ${ }^{1}$

\footnotetext{
${ }^{1}$ Hendrik. (2011). Etika Dan Hukum Kesehatan. Jakarta: Buku Kedokteran EGC. p. 176.
} 
One of the most basic needs for humans besides their need for law is their need in the health sector. Related to this need, the Indonesian government also guarantees this through Article $28 \mathrm{H}$ paragraph (1) of the 1945 Constitution which reads "Everyone has the right to live in physical and spiritual prosperity, to live, and to have a good and healthy living environment and the right to obtain services of health". Coupled with Article 34 paragraph (3) which reads "The state is responsible for the provision of proper health service facilities and public service facilities". From the sound of the two articles, it means that the government has an obligation to provide health services to every citizen of its country.

The legal problems in the current era of globalization in the fields of economy, politics and business are never ending. Legal problems in this era of globalization that are always developing are crimes. Crime is a complex phenomenon that can be understood from many different sides. That is why in everyday life we can catch various comments about a crime that are different from one another. ${ }^{2}$

One of the crimes and law violations in the health sector that is rife today is crime in the pharmaceutical sector. This is because in the world of pharmacy, there are professions concerning the art and methods of providing drugs, either from natural or synthetic sources that are suitable for distribution and use in the treatment and prevention of diseases. Meanwhile, pharmaceutical preparations are drugs, medicinal ingredients, traditional medicines, and cosmetics.

In the current era of globalization, human needs are increasingly complex, many attractive advertisements, especially medicinal products and cosmetic products, without describing side effects and clear information that these products are safe for consumption so that consumers are interested in buying them, while sometimes consumers themselves does not pay attention to the circulation of drugs and cosmetics with a license or not. However, the increasing consumer demand for medicinal products is exploited by several business actors, including producers, distributors and retailers who distribute drugs without a distribution permit (illegal), whose safety and benefits are not guaranteed.

The state of criminal law arises a need or desire to take action against those who cause harm to individual interests, therefore he begins to realize that actions that harm individual interests are also a violation of the interests of society. So in order to end the recurring revenge, it was decided that a person who incurs losses to the interests of others must pay compensation to the person who has been injured, as well as to the community. ${ }^{3}$

The threat of serious imprisonment from statutory regulations and the application of high imprisonment from court demands and decisions is not absolute sanction (determinate sentence). We do not have to think about the threat of serious penalties and the application of high penalties, if our knowledge is oriented towards criminal developments and the implementation of new imprisonment. Legislation that contains the threat of serious criminal sanctions is actually the maximum limit that is predicted by the legislative bodies, while the

\footnotetext{
2 Topo Santoso, and Eva Achjani Zulfa. (2001). Kriminologi. Jakarta: Raja Grafindo Persada. p. 1.

3 Satochid Kartanegara. (1995). Hukum Pidana Bagian I. Jakarta: Balai Lektur Mahasiswa. p.24.
} 
high penalty application is the upper limit that can be considered by the applicants of criminal law in accordance with the prevailing laws and regulations. ${ }^{4}$

One of the crimes in health law that often occurs today is a crime in the pharmaceutical sector. Pharmacy is a profession that deals with the arts and sciences in providing natural resource materials and synthetic materials that are suitable and fun to distribute and use in the treatment and prevention of a disease. Where, seeing the current state of society, it is very possible for people to import goods without customs or the goods sold are illegal or smuggled.

The objectives of this study are as follows: To find out and analyze the investigator's authority to handle the unauthorized distribution of cosmetics in the construction of the legal system; To find out and analyze the implementation of Article 197 in conjunction with Article 106 paragraph (1) subside Article 196 in conjunction with Article 98 paragraph (2) and paragraph (3) of Act No. 36 of 2009 concerning Health in the conception of legal certainty.

\section{Research methods}

The approach method used in the preparation of this legal writing is to use a sociological juridical approach, namely seeing the law as human behavior in society. ${ }^{5}$ The specification of this research is descriptive analytical.

\section{Result and Discussion}

\subsection{The Authority of Investigators to Handle the Unauthorized Distribution of Cosmetics in Construction of Legal System}

Law is statutory regulation made by a power, in regulating the interaction of life in society. Health law according to the Articles of Association of the Indonesian Health Law Association (PERHUKI), are all legal provisions that are directly related to health care / services and their implementation. This concerns the rights and obligations of both individuals and all levels of society as recipients of health services as well as from health service providers in all aspects, organizations, facilities, guidelines for medical service standards, health science and law and other legal sources. Medical law is part of health law, which concerns medical care / service. ${ }^{6}$

Eradication efforts are defined as efforts to minimize and reduce the crime of cosmetic distribution without distribution permits and to improve the settlement of cases to achieve the legal objectives, namely creating justice, certainty and benefit In order to achieve these legal objectives, the investigators of the State Police of the Republic of Indonesia and civil servant investigators of the Central Food and Drug Control Center have made repressive and preventive measures against these crimes.

\footnotetext{
${ }^{4}$ Bambang Poernomo. (1988). Kapita Selekta Hukum Pidana. Yogyakarta: Dosen Fakultas Hukum UGM. p. 5.

${ }^{5}$ Anonim. (2012). Pedoman Penulisan Hukum. Fakultas Hukum UMM. p.18.

${ }^{6}$ Hanafiah and, M.Yusuf. (1999). Etika Kedokteran dan Hukum Kesehatan. Jakarta: EGC. p.3.
} 
An investigator is a person who carries out an "investigation". Investigation means a series of actions to seek and find a situation or event that is related to a crime and a criminal offense or is suspected of being a criminal act. ${ }^{7}$

Investigation activities are part or one of the ways to carry out investigations to: 1 . determine that an event that occurs is a criminal act or not; 2 . to make light of a case to determine the perpetrator; and 3. serve as the basis for making coercive measures. ${ }^{8}$

The investigators' powers to handle the unauthorized distribution of cosmetics in the construction of the legal system include:

- receive a report or complaint from someone about the existence of a criminal act;

- take the first action at the scene;

- order a suspect to stop and check the suspect's identification;

- carry out an arrest, detention, search and confiscation;

- carry out inspection and confiscation of letters;

- take fingerprints and take a picture of a person;

- summon people to be heard and examined as suspects or witnesses;

- bring in the necessary experts in connection with the case examination;

- to terminate the investigation;

- take other action according tolawresponsible.

\subsection{Implementation in the conception of legal certainty}

Based on the objectives of codification and unification, in the manner of a criminal process that will be examined, tried in the general court environment must be based on Act No. 8 of 1981 concerning the criminal code of law. Although basically the Law of the Republic of Indonesia number 36 of 2009 concerning Health and Act No. 8 of 1981 concerning criminal procedures have an equal position, the two laws have different functions because, Act No. 36 of 2009 Health is a material legal provision that functions to regulate and determine obligations, prohibitions or criminal sanctions,

Security and use of pharmaceutical preparations and medical devices are further regulated in Articles 98, 99, 104, 105, 106, 107 and 108 of Act No. 36 of 2009 concerning Health. In Chapter XX of this law it regulates criminal provisions from Article 190 to Article 201. Because it contains criminal provisions, Act No. 36 of 2009 concerning Health, including administrative criminal law, especially in the field of social welfare. According to Barda Nawawi Arief, ${ }^{9}$ Administrative criminal law is essentially an embodiment of the policy of using criminal law as a means of enforcing / implementing administrative law.

The role of law enforcement officers, especially investigators is very strategic, investigators are the main gateway to starting the task of seeking

\footnotetext{
${ }^{7}$ Bambang Tri Bawono. Tinjauan Yuridis Hak-Hak Tersangka Dalam Pemeriksaan Pendahuluan. Jurnal Hukum Vol XXVI, No. 2, August 2011.

${ }^{8}$ Hera Saputra and, Munsyarif Abdul Chalim. Penerapan Sistem Pemidanaan Terhadap Pelaku Tindak Pidana Penyalahgunaan Narkoba (Studi Kasus di Polda Jateng). Jurnal Daulat Hukum Vol. 1. No. 1 March 2018 ISSN: 2614-560X.

${ }^{9}$ Barda Nawawi, Arief. (2003). Kapita Selekta Hukum Pidana. Bandung: Citra Aditya Bakti. p.15-16.
} 
material truth because through the investigation process, law enforcement efforts are actually starting to be made in order to create legal certainty.

The government has also determined that medicines, medicinal ingredients, traditional medicines, cosmetics and medical devices can only be circulated after obtaining a distribution permit (see Article 106 paragraph [1] in conjunction with Article 1 paragraph [4] UU no. 36 of 2009 concerning Health). So, if the Sinsei circulates drugs without a distribution permit, the Sinsei violates Article 197 of Law 36/2009 which states that everyone who deliberately produces or distributes pharmaceutical preparations and / or medical devices does not have a distribution permit as referred to in Article 106 paragraph (1) shall be sentenced to imprisonment for a maximum of 15 (fifteen) years and a maximum fine of IDR $1,500,000,000.00$ (one billion five hundred million rupiah).

Implementation of Article 197 in conjunction with Article 106 paragraph (1) subsidiary to Article 196 in conjunction with Article 98 paragraph (2) and paragraph (3) of Act No. 36 of 2009 concerning Health in the conception of legal certainty it is very appropriate to receive appropriate punishment because actions are very detrimental to the wider community both from an economic, social, and cultural perspective.

\section{Closing}

Based on the research, it can be concluded that the investigator's authority to handle the distribution of cosmetics without a permit in the construction of the legal system includes: receiving a report or complaint from someone about the existence of a criminal act; take the first action at the scene; order a suspect to stop and check the suspect's identification; carry out an arrest, detention, search and confiscation; carry out inspection and confiscation of letters; take fingerprints and take a picture of a person; summon people to be heard and examined as suspects or witnesses; bring in the necessary experts in connection with the case examination; to terminate the investigation; take other action according tolawresponsible.Implementation of Article 197 in conjunction with Article 106 paragraph (1) subsidiary to Article 196 in conjunction with Article 98 paragraph (2) and paragraph (3) of Act No. 36 of 2009 concerning Health in the conception of legal certainty it is very appropriate to receive appropriate punishment because actions are very detrimental to the wider community both from an economic, social, and cultural perspective. The public is demanded to be more willing to seek information about cosmetics sold in the market so that people are smarter in choosing and sorting the cosmetics used and so that people know how dangerous the side effects of using cosmetics that do not have a distribution license are because these cosmetics are made from ingredients harmful to health.

\section{References}

\section{Journals:}

[1] Bambang Tri Bawono. Tinjauan Yuridis Hak-Hak Tersangka Dalam Pemeriksaan Pendahuluan. Jurnal Hukum Vol XXVI, No. 2, August 2011. 
[2] Hera Saputra and, Munsyarif Abdul Chalim. Penerapan Sistem Pemidanaan Terhadap Pelaku Tindak Pidana Penyalahgunaan Narkoba (Studi Kasus di Polda Jateng). Jurnal Daulat Hukum Vol. 1. No. 1 March 2018 ISSN: 2614$560 \mathrm{X}$.

\section{Books:}

[1] Anonim. (2012). Pedoman Penulisan Hukum. Fakultas Hukum UMM.

[2] Bambang Poernomo. (1998). Kapita Selekta Hukum Pidana. Yogyakarta: Dosen Fakultas Hukum UGM.

[3] Barda Nawawi, Arief. (2003). Kapita Selekta Hukum Pidana. Bandung: Citra Aditya Bakti.

[4] Hanafiah, M.Yusuf. (1999). Etika Kedokteran dan Hukum Kesehatan. Jakarta: EGC.

[5] Hendrik. (2011). Etika Dan Hukum Kesehatan. Jakarta: Buku Kedokteran EGC. .

[6] Satochid Kartanegara. (1995). Hukum Pidana Bagian I. Jakarta: Balai Lektur Mahasiswa.

[7] Topo Santoso and, Eva Achjani Zulfa. (2001). Kriminologi. Jakarta: Raja Grafindo Persada. 